\title{
PENGETAHUAN IBU HAMIL TENTANG GIZI SELAMA KEHAMILAN PADA SALAH SATU DESA DI KABUPATEN GARUT
}

\author{
Lilis Mamuroh*, Sukmawati*, Restu Widiasih* \\ Fakultas Ilmu Keperawatan Universitas Padjadjaran \\ Email: lilis.mamuroh@gmail.com
}

\begin{abstract}
Asupan nutrisi yang cukup adalah fakor yang sangat penting yang mempengaruhi kehamilan. Wanita dengan kehamilan usia dini atau berjarak dekat berada pada faktor resiko memasuki kekurangan cadangan butrisi. Deplesi nutrisi ibu dapat berkontribusi pada peningkatan insiden kelahiran prematur dan reterdasi pertumbuhan janin serta peningkatan resiko kematian ibu dan morbiditas. Nutrisi memainkan peranan utama dalam kesehatan ibu dan anak. Status gizi ibu yang buruk telah terkait dengan hasil kelahiran yang merugikan namun, hubungan antara gizi ibu dan hasil kelahiran yang kompleks dipengaruhi banyak faktor antara lain faktor biologis, sosial ekonomi, pengetahuan dan faktor demografi yang bervariasi dalam populasi yang berbeda. Tujuan dari penelitian ini adalah untuk mengetahui dan mendapatkan gambaran yang jelas tentang pengetahuan ibu hamil di sebuah desa pada Kabupaten Garut. Metode Penelitian yang digunakan adalah deskriptif. Populasi yang diambil total sampling yaitu 29 responden Metoda pengumpulan data dilakukan dengan menggunakan instrument test dan pengolahan data dilakukan dengan metode distribusi prosentase. Hasil penelitian didapatkan bahwa secara keseluruhan tingkat pengetahuan ibu hamil dikatagorikan baik dengan prosentase $69 \%$
\end{abstract}

Kata Kunci: Pengetahuan, Ibu Hamil, Gizi selama kehamilan

\section{LATAR BELAKANG}

Kehamilan manusia terjadi selama 40 minggu antara waktu menstruasi terakhir dan kelahiran (38 minggu dari pembuahan. Istilah medis untuk wanita hamil adalah gravida, sedangkan manusia didalamnya disebut embrio (minggu-minggu awal) kemudian janin(sampai kelahiran).

Didalam kandungan terjadi proses tumbuh kembang dalam waktu 40 minggu, yang dimulai dari 2 sel yang kemudian menjadi bayi sempurna dengan berat badan 2,5 - $4 \mathrm{~kg}$. Sejumlah otot, tulang, darah dan alat tubuh lain dibuat dari zat-zat gizi yang berasal dari makanan ibu. Zat-zat gizi tersebut dialirkan melalui plasenta kedalam tubuh janin.

Selama kehamilan, kenaikan berat badan ibu mempengaruhi pertumbuhan janin. Ukuran neonatus kecil saat lahir disebabkan pertumbuhan yang buruk dan pendeknya usia kehamilan, dan hasil yang paling tidak baik terjadi pada bayi yang paling matang. Rendahnya berat badan pada waktu kehamilan dikaitkan dengan peningkatanresiko kelahiran prematur, sedangkan rendahnya berat badan ibu pada trimester kedua dan ketiga terbukti berhubungan dengan resiko kelahiran prematur spontan.

Dua faktor yang berhubungan dengan gizi ibu menunjukan hubungan positif dengan berat badan bayi lahir indeks masa tubuh ibu sebelum hamil (BMI, yang didefinisikan sebagai berat badan/ tinggi) dan berat badan selama kehamilan. Wanita BMI rendah sebelum hamil berada pada peningkatan resiko untuk kelahiran prematur dan reterdasi pertumbuhan intrauterine (IUGR). Namun wanita dengan BMI rendah sebelum hamil memiliki resiko kelahiran prematur hanya jika gagal untuk mendapatkan berat badan yang memadai.

Peningkatan berat badan yang sesuai usia kehamilan dapat membantu meningkatkan kesehtana ibu dan janin. Peningkatan berat badan ibu yang tidak sesuai telah dikaitkan dengan berat badan lahir rendah $(<2500 \mathrm{gr})$ sedangkan peningkatan berat badan berlebih menyebabkan berat lahir yang tinggi $(<4000$ gr $)$ dan obesitas setelah melahirkan. Data dari Canadian Maternity 
Experiences Survey menunjukan bahwa wanita hamil yang mendapatan berat badan kurang dari yang direkomendasikan cenderung melahirkan bayi dengan berat badan kurang dari 2500 gr.

Pasokan nutrisi yang cukup adalah fakor yang sangat penting yang mempengaruhi kehamilan. Wanita dengan kehamilan usia dini atau berjarak dekat berada pada faktor resiko memasuki kekurangan cadangan butrisi. Deplesi nutrisi ib dapat berkontribusi pada peningkatan insiden kelahiran prematur dan reterdasi pertumbuhan janin serta peningkatan resiko kematian ibu dan morbiditas.

Nutrisi memainkan peranan utama dalam kesehatan ibu dan anak. Status gizi ibu yang buruk telah terkait dengan hasil kelahiran yang merugikan namun, hubungan antara gizi ibu dan hasil kelahiran yang kompleks dipengaruhi banyak faktor antara lain faktor biologis, sosial ekonomi, pengetahuan dan faktor demografi yang bervariasi dalam populasi yang berbeda.

Kurangnya pengetahuan ibu hamil tentang pentingnya gizi selama kehamilan berdampak buruk bagi janin. Salah satu fenomena yang terjadi di Desa Sudalarang Kecamatan Sukawening kabupaten Garut terdapatnya kematian bayi prematur dengan berat badan kurang dari normal dikarenakan ibu kurang memperhatikan gizi selama hamil. Dari fenomena yang terjadi diatas dapat disimpulkan bahwa pengetahuan ibu hamil tentang pentingnya gizi selam kehamilan sangat penting,

\section{METODE}

Metode penelitian yang digunakan dalam penelitian ini adalah deskriptif yaitu mengumpulkan data dan kemudian dianalisa untuk mengetahui gambaran yang berhubungan dengan suatu fenomena yang sedang terjadi. Dengan menggunakan metode tersebut diharapkan akan dapat menggambarkan pengetahuan ibu hamil tentang pentingnya gizi selama kehamilan di salah satu desa pada Kabupaten Garut.

Populasi dalam penelitian ini adalah seluruh ibu hamil di salah satu desa pada
Kabupaten Garut yang berjumlah 29 orang. Sampel dalam penelitian ini menggunakan total sampling yaitu seluruh populasi dijadikan sampling yang berjumlah 29 orang. Metoda

Pengumpulan data dilakukan dengan menggunakan instrument test berupa soal yang dikumpulkan dengan cara tes tertulis (paper based test). Selanjutnya data diolah dan dianalisi dengan bantuan peranngkat lunak komputer.

\section{HASIL}

Tabel 1: Distribusi Pengetahuan Responden Tentang Pentingnya Gizi Selama Kehamilan

\begin{tabular}{lcc}
\hline \multicolumn{1}{c}{ Pengetahuan } & f & $\%$ \\
\hline Baik & 20 & 69,0 \\
\hline Cukup & 5 & 17,2 \\
\hline Kurang & 4 & 13,8 \\
\hline Jumlah & 29 & 100 \\
\hline
\end{tabular}

Tabel di atas menunjukan angka pengetahuan ibu hamil tentang pentingnya gizi selama kehamilan yang didata yaitu tentang pengertian gizi, fungsi zat gizi, gizi bagi ibu hamil dan dampak kekurangan gizi terhadap ibu hamil. Adapun hasilnya tingkatan pengetahuan baik dengan jumlah 20 responden prosentasenya 69,) \%, tingkatan pengetahuan Cukup dengan jumlah 5 responden dengan prosentase $17,2 \%$, dan tingkatan pengetahuan Kurang dengan jumlah responden 4 prosentase $13,8 \%$.

Tabel 2: Distribusi Pengetahuan Responden tentang Pengertian Gizi Ibu Hamil

\begin{tabular}{lcc}
\hline \multicolumn{1}{c}{ Pengetahuan } & f & $\%$ \\
\hline Baik & 25 & 86,2 \\
\hline Cukup & - & - \\
\hline Kurang & 4 & 13,8 \\
\hline Jumlah & 29 & 100 \\
\hline
\end{tabular}

Tabel di atas menunjukan pengetahuan ibu hamil tentang pentingnya gizi selama kehamilan tentang pengertian gizi, pengetahuan ibu baik yaitu 25 responden dengan angka presentase $86,2 \%$ tingkatan 
pengetahuan Cukup dengan jumlah responden 0 angka presentae $0 \%$, dan tingkat pengetahuan Kurang jumlah 4 responden dengan nilai presentase $13,8 \%$.

Tabel 3: Distribusi Pengetahuan Responden tentang Fungsi Gizi bagi Selama Kehamilan

\begin{tabular}{lcc}
\hline \multicolumn{1}{c}{ Pengetahuan } & f & $\%$ \\
\hline Baik & 19 & 65,5 \\
\hline Cukup & 8 & 27,6 \\
\hline Kurang & 2 & 6,9 \\
\hline Jumlah & 29 & 100 \\
\hline
\end{tabular}

Tabel di atas menunjukan tingkat pengetahuan ibu hamil tentang pentingnya gizi selama kehamilan tentang fungsi zat gizi tingkat pengetahuan baik jumlah responden 19 responden dengan prosentase 65,5\% , tingkat pengetahuan Cukup jumlah 8 responden dengan prosentase 27,6 dan tingkat pengetahuan kurang jumlah 2 responden dengan prosentase $6,9 \%$

Tabel 4: Distribusi Pengetahuan Responden Tentang Jenis-jenis Gizi Bagi Ibu Hamil

\begin{tabular}{lcc}
\hline \multicolumn{1}{c}{ Pengetahuan } & f & $\%$ \\
\hline Baik & 12 & 41,4 \\
\hline Cukup & 10 & 34,5 \\
\hline Kurang & 7 & 24,1 \\
\hline Jumlah & 29 & 100 \\
\hline
\end{tabular}

Tabel di atas menunjukan tingkat pengetahuan ibu tentang pentingnya gizi selama kehamilan tentang jenis-jenis gizi bagi ibu hamil adalah baik dengan jumlah 12 responden angka prosentasenya 41,4\%, tingkatan pengetahuan Cukup dengan jumlah responden 10 orang angka presentasenya $34,5 \%$, dan tingkatan pengetahuan Kurang dengan jumlah 7 responden angka prosentasenya $24,1 \%$.
Tabel 5: Distribusi Pengetahuan Responden tentang Dampak Kekurangan Gizi Terhadap Ibu Hamil

\begin{tabular}{lcc}
\hline Pengetahuan & f & $\%$ \\
\hline Baik & 11 & 38,0 \\
\hline Cukup & 9 & 31,0 \\
\hline Kurang & 9 & 31,0 \\
\hline Jumlah & 29 & 100 \\
\hline
\end{tabular}

Tabel di atas menunjukan tingkat pengetahuan ibu tentang pentingnya gizi selama kehamilan tentang dampak kekurangan gizi bagi ibu hamil tingkat pengetahuan Baik dengan jumlah 11 responden angka prosentasenya 38,0 \%, tingkat pengetahuan Cukup dengan jumlah 9 responden dengan nilai prosentasenya $31,0 \%$ dan tingkat pengetahuan Kurang jumlah 9 responden dan prosentasenya adalah 31,0\%.

\section{PEMBAHASAN}

Berdasarkan hasil penelitian di Desa Sudalarang Kecamatan Sukawening kabupaten Garut menunjukan bahwa sebagian besar tingkat pengetahuan ibu hamil tentang gizi selama kehamilan dapat dikatagorikan baik $(69,0 \%)$.

Banyak Faktor eksterna dan interna yang menyebabkan hal tersebut terjadi mungkin kebiasaan, tingkat pendidikan,sosial, ekonomi yang bisa menimbulkan perbedaan pengetahuan, pendapat dan pola hidup.

Menurut Notoatmodjo pengetahuan adalah hasil dari tahu dan ini terjadi setelah orang melakukan penginderaan terhadap suatu obyek tertentu. Penginderaan terjadi melalui pancaindera manusia, yakni : indra penglihatan, pendengaran, penciuman. Rasa dan raba. Sebagian besar pengetahuan manusia diperoleh melalui mata dan telinga. Pengetahuan atau kognitif merupakan domain yang sangat penting untuk terbentuknya tindakan seseorang (overt behavior).

Menurut Notoatmodjo (2003) juga menjelaskan bahwa pengetahuan atau merupakan domain penting dalam 
membentuk perilaku seseorang. Perilaku yang dilandasi dengan pengetahuan yang baik akan menghasilkan perilaku yang baik. Menurut Wahyudi dkk (2016) seseorang yang tidak didasari dengan pengetahuan maka sulit untuk bertindak dan menerapkan gaya hidup sehat termasuk untuk memenuhi kebutuhan gizi selama kehamilan.

Menurut Purwanti, Macfoedz \& Wahyuningsih (2014), pengetahuan ibu hamil tentang nutrisi dengan baik dapat mempengaruhi perilaku ibu khususnya berkaitan dengan konsumsi makanan. Dengan pengetahuan yang baik tentunya pola makan dan perilaku ibu dalam mengonsumsi makanan lebih memperhatikan kualitan kandungan gizi dibadingkan kuantitas atau banyaknya makanan yang dikonsumsi. Dengan mengonsumsi makanan yang banyak mengandung nutrisi tentunya dapat meningkatkan kesehatan dan pertumbuhan ibu dan balita. Dengan demikian pengetahuan tentang nutrisi bagi ibu sangat penting.

Pada hasil penelitian di atas menunjukan pengetahuan ibu hamil terhadap pengertian gizi yang menjadikan salah satu bagian dari pentingnya gizi selama kehamilan yaitu angka prosentase tertinggi pada tingkatan baik $(86,2 \%)$.

Gizi atau nutrition adalah suatu proses organisme menggunakan makanan yang dikonsumsi secara normal melaluiproses digesti, absorpsi, tranportasi, penyimpanan, metabolisme dan pengeluaran zat-zat yang tidak digunakan untuk mempertahankan kehidupan, pertumbuhan dan fungsi normal dari organ-organ serta menghasilkan energi.

Makanan adalah bahan selain obat yang mengandung zat-zat gizi dan atau unsur-unsur ikatan kimia yang dapat diubah menjadi zat gizi oleh tubuh yang berguna bila dimasukan ke dalam tubuh. Bahan makanan adalah makanan dalam keadaan mentah. Status gizi adalah keadaan tubuh sebagai akibat konsumsi makanan dan penggunaan zat-zat gizi (Almatsier 2015). Hasil penelitian juga menunjukan pengetahuan ibu hamil terhadap fungsi zat gizi yang menjadikan salah satu bagian dari pentingnya gizi selama kehamilan yaitu angka prosentase tertinggi pada tingkatan baik $(65,5 \%)$.
Menurut Almatsier (2015) fungsi zat gizi diantaranya untuk memberi energi (zat pembakar), pertumbuhan dan perkembangan jaringan tubuh (zat pembangun) dan untuk pengatur proses tubuh (zat pengatur) dimana zat gizi tersebut terkandung didalam karbohidrat, protein, mineral, lemak, vitamin, zat besi dan lain-lain. Maka sebuah kemungkinan yang besar apabila pengetahuan ibu hamil kurang akan terjadi ketidakpedulian terhadap asupan gizi ketiak hamil.

Tingkat pengetahuan ibu hamil tentang gizi selama kehamilan terhadap jenis-jenis gizi bagi ibu hamil baik dengan angka presentase $41,4 \%$ dapat mencerminkan bahwa ibu hamil tingkat pengetahuannya baik. Menurut Arisman (2010). Jenis-jenis gizi bagi ibu hamil diantaranya cukup kalori untuk dapat membentuk lebih banyak jaringan tubuh bukan lemak seperti yang terkandung pada karbohidrat, protein, mineral air, yaitu.

Kurangnya pengetahuan ibu hamil tentang gizi selama kehamilan akan berdampak terhadap terjadinya kekurangan gizi pada ibu hamil. Menurut Arisman (2010) dampak kekurangan gizi terhadap ibu hamil yaitu dapat menimbulkan anemia gizi besi yang banyak terdapat di Indonesia maka ibu hamil dianjurkan untuk mendapat tambahan zat besi atau makanan yang mengandung zat besi. Selain itu, dampak kekurangan gizi terhadap ibu hamil dapat terjadi kenaikan berat badan yang rendah selama kehamilan dan menimbulkan mual muntah (hiperemesis gravidarum).

Berdasarkan penelitian Ilmiani (2019) disimpulan bahwa terdapat hubungan pengetahuan gizi ibu hamil terhadap peningkatan berat badan selama kehamilan di Puskesmas Bandar Lampung. Dengan demikian semakin baik pengetahuan ibu hamil tentang gizi diharapkan dapat meningkatkan berat badan ibu hamil secara normal selama proses kehamilan.

Hasil penelitian ini dikuatkan dengan hasil penelitian Wahyuni (2008) bahwa ada hubungan yang bermakna antara pengetahuan dengan status gizi ibu hamil. Pada dasarnya pemberian pengetahuan tentang status gizi ibu hamil adalah bagian 
dari upaya untuk mengoptimalkan kemampuan ibu, sehingga dengan pengetahuan gizi yang baik diharapkan ibu hamil memiliki status gizi yang baik pula. merupakan hasil dari tahu, dan ini terjadi setelah orang melakukan.

\section{KESIMPULAN}

Pengetahuan ibu hamil secara umum pada penelitian ini sebagian besar baik. Bila ditinjau berdasarkan topik, hasil penelitian juga menunjukan pengetahuan ibu hamil pada tingkat baik untuk topik: pengertian gizi, fungsi gizi, jenis-jenis gizi maupun dampak

Berdasarkan simpulan tersebut, maka disarankan untuk melakukan promosi kesehatan dan memberikan penyuluhan tentang gizi pada ibu-ibu yang pengetahuannya masih kurang. Selain itu disarankan untuk memotivasi ibu hamil agar mengaplikasikan pengetahuan baiknya ke dalam perilaku pemenuhan gizi pada kehamilan.

\section{DAFTAR PUSTAKA}

Almatsier, S. (2015). Prinsip Dasar Ilmu Gizi. Jakarta : PT Gramedia Pustaka Utama.

Arisman. (2010). Buku Ajar Ilmu Gizi, Gizi dalam Daur Kehidupan. Jakarta: EGC.

Ilmiani, TK. (2019). Hubungan Pengetahuan Gizi Ibu Hamil dengan Peningkatan Berat Badan Selama Kehamilan di Puskesmas Bandar Lampung. Skripsi, Universitas Lampung.

Notoatmodjo. S. (2003). Pendidikan Dan Perilaku Kesehatan. Jakarta: Rineka. Cipta.

Purwanti, I. Macfoedz, I \& Wahyuningsih. (2014). Pengetahuan Tentang Nutrisi Berhubungan dengan Status Anemia Pada Ibu Hamil di Puskesmas Sewon II Bantul Yogyakarta Tahun 2012. Jurnal Gizi Dan Dietetik Indonesia, 62-67.

Wahyudi, AS. Suarilah, I. Mumpuningtias, ED \& Astutik, MF. (2016). Peningkatan Pengetahuan dan Sikap Ibu Dalam Pemenuhan Gizi Selama Kehamilan Melalui Promosi Kesehatan. Jurnal INJEC, 178-186.

Wahyuni, S. (2008). Hubungan Pengetahuan Ibu Hamil Tentang Gizi dengan Status Gizi Ibu Hamil Trimester III di Puskesmas Colomadu II Karanganyar, Skripsi, Universitas Sebelas Maret Surakarta. 